\title{
The Critical Enterprise in Translating Black Women Writers' Authorship: A Description on Who Slashed Celanire's Throat? and The Women of Tijucopapo
}

\author{
Norma Diana Hamilton \\ norma.diana@unb.br \\ https://orcid.org/0000-0002-9137-1928 \\ University of Brasilia, Brazil \\ Israel Victor de Melo \\ israelvictor398@gmail.com \\ https://orcid.org/0000-0001-6662-9694 \\ University of Brasilia, Brazil
}

\begin{abstract}
This paper is focused on the critical enterprise involved in the translation of Black female authorship from Afro-Caribbean and Latin American contexts into the English language. More specifically, it looks at the circumstances of the translation of the fictional narratives Célanire cou-coupé (2000) by the Guadeloupian Maryse Condé and As mulheres de Tijucopapo (1982) by the Brazilian Marilene Felinto, as well as the publications of the versions in English: Who slashed Celanire's Throat? (2004) and The Women of Tijucopapo (1994), respectively. We take on a cultural perspective within the field of translation studies and it may be inserted within the theoretical and descriptive branch, being product-process oriented. From general cultural social theories, we draw on the works of Black female intellectuals, Lélia Gonzalez, Patricia Hill-Collins, Denise Carrascosa, and many others, in dialogue with the perspectives of cultural theorists from translation studies, André Lefevere, Lawrence Venuti, and others. Based on the models of descriptive analysis within this field by Gideon Toury and others, we propose a description of the translation (process and product) of Condé's and Felinto's novels.
\end{abstract}

Keywords: politics of translation, Black female authorship in the Caribbean and Latin-America, coloniality of gender, intersectionality, Mestizo translation.

El proyecto crítico de traducir la autoría de escritoras negras: una descripción de Who Slashed Celanire's Throat? y The Women of Tijucopapo

\section{Resumen}

Este artículo se concentra en el proyecto crítico de traducir la autoría de escritoras negras de contextos afrocaribeños y latinoamericanos a la lengua inglesa. En específico, aborda las circunstancias de la traducción de las narrativas ficticias Célanire cou-coupé (2000), de la guadalupeña Maryse Condé, y 
As mulheres de Tijucopapo (1982), de la brasileña Marilene Felinto, al igual que de la publicación de las versiones en inglés: Who Slashed Celanire's Throat? (2004) y The Women of Tijucopapo (1994), respectivamente. Adoptamos un enfoque cultural dentro del campo de la traductología, que puede insertarse dentro de la rama teórica y descriptiva, orientado hacia el producto y el proceso. Nos apoyamos, respecto a las teorías sociales culturales generales, en los trabajos de intelectuales negras: Lélia Gonzalez, Patricia Hills-Collins, Denise Carrascosa, entre muchas otras, en diálogo con las perspectivas de teóricos culturales de la traductología, como André Lefevere, Lawrence Venuti y otros. Basándonos en los modelos de análisis descriptivo dentro de la traductología de Gideon Toury y otros, proponemos una descripción de la traducción (proceso y producto) de las novelas de Condé y Felinto.

Palabras clave: políticas de la traducción, escritura de mujeres negras en Latinoamérica y el Caribe, colonialidad de género, interseccionalidad, traducción mestiza.

\section{L'Action critique vers la traduction des productions des écrivaines noires: une description de Who slashed Celanire's throat? et The Women of Tijucopapo}

\section{Résumé}

Cet article se concentre sur l'action critique liée à la traduction, en langue anglaise, de productions écrites par des femmes noires dans les contextes Afro-Antillais et Latino-Américains. Plus précisément, nous analysons les circonstances de traduction des récits fictifs Célanire cou-coupé (2000), de la Guadeloupéenne Maryse Condé, et As Mulheres de Tijucopapo (1982), de la Brésilienne Marilene Felinto, ainsi que les publications des versions anglaises : Who slashed Celanire's throat? (2004) et The Women of Tijucopapo (1994), respectivement. Nous prenons comme perspective l'approche culturelle dans le champ des Études de Traduction, qui peut s'inscrire dans le domaine théorique et descriptif, étant guidé par son processus de production. Sur la base des théories sociales culturelles générales, nous nous appuyons sur les travaux des intellectuelles noires Lélia Gonzalez, Patricia Hill-Collins, Denise Carrascosa et bien d'autres, en dialogue avec les perspectives des théoriciens culturels des études de traduction, André Lefevere, Lawrence Venuti et bien d'autres. Sur la base des modèles d'analyse descriptive du domaine par Gideon Toury entre autres, nous proposons une description de la traduction (processus et production) des romans de Condé et Felinto.

Mots-clés : politiques de traduction, productions des femmes noires dans les littératures des Caraïbes et d'Amérique latine, colonialité du genre, intersectionnalité, traduction métisse. 


\section{Introduction}

Black female literature from the Caribbean and Latin America is part of a literary tradition that has been identified as peripheral in relation to traditional Eurocentric literature, as it comes from voices that have been marginalized, voices of the ex-colonized. Such voices have fought to give visibility to questions related to the interface of race and gender within patriarchal Eurocentric societies, in which their experiences up-to-date are negotiated and compromised by the trace of the history of colonization.

By portraying the different forms of oppression that Black women face in such societies, as well as indicating pathways to social justice, Black female authorship from the Caribbean and Latin America becomes an artistic manifestation that counters the Eurocentric literary tradition, in which Black culture and identity have been represented inadequately and, as such, obscured. Black female authorship, within a spectrum of artistic manifestations of Black culture, contributes to constructing a space in which Black women may express their subjectivities, with the aim of creating adequate and just representations of themselves.

As such, in our perspective, the work of the translation of Black female literature is of utmost importance, as it may contribute to an increase in the dissemination and visibility of the enterprise of Black women's writing. In referring specifically to the Brazilian context, Brazilian researchers Cibele Araújo, Luciana Silva and Dennys Silva-Reis speak out against the general negligence of the Black female voice when it comes to giving visibility to cultural productions in translation. They point out that "the choice of the work to be translated could level out the playfield of feminine representations, contributing to Black women's right to seeing themselves in a positive way in literature and in the cultural products that they consume" (Araújo et al., 2019, p. 6, our translation).

This paper takes on a cultural perspective within the field of Translation Studies (thereby, Ts) and it may be inserted within the theoretical and descriptive branch, being product-process oriented. From general cultural social theories, we draw on the works of Black female intellectuals, Lélia Gonzalez, Patricia Hill-Collins, Denise Carrascosa, and others, in dialogue with the perspectives of cultural theorists from TS, André Lefevere, Lawrence Venuti, and others. Based on the models of descriptive analysis within ts by Gideon Toury and others, we propose a description of the translation (process and product) of Condé's and Felinto's novels.

The general objective of this article is to discuss the political agency of the translation of Afro-Caribbean and Latin American female authorship with focus on the novels aforementioned. By political agency we refer to the evident concern and efforts of the translator and other people or organizations involved in the translation project, in giving visibility to what is valued in the ST: the protagonist, his/her story and cultural setting, as well as the literary aspects specific to the author. Such an agency or critical enterprise of the translation points to an orientation towards the ST. As such, the specific objectives of this research include discussing the circumstances in which the works were selected for translation and published; pinpointing decisions made by the translator at the level of word choices related principally to the interface of race and gender; and identifying the translation strategy employed.

The relevance of the proposal of this paper is its intended contribution to the visibility of the translation of Black female authorship from Afro-Caribbean and Latin American contexts. 


\section{8}

\section{Theoretical premises}

In Western academia, the categorization of Black female authorship from the Caribbean and Latin America as Third World means that that space will be regulated from a Eurocentric perspective in interpretation and translation practices. As the Indian scholar Aijaz Ahmad (1994) points out, Third World literature does not come to us directly but through interpretation based on metropolitan countries: "by the time a Latin American novel arrives in Delhi, it has been selected, translated, published, reviewed, explicated and allotted a place in the burgeoning archive of Third World Literature through a complex set of metropolitan mediations" (1994, p. 45).

Within that process of cultural domination, the knowledge produced by the colonized was neglected and obscured, represented as inferior to Eurocentric epistemology. Sueli Carneiro (2005), Afro-Brazilian intellectual, recovers the concept of epistemicide to describe the processes of depreciation, elimination or delegitimization of non-hegemonic knowledge. In the Brazilian context, the white and male intellectual cultural elite maintains certain relationship of domination in opposition to the knowledge and epistemological practices of Black and indigenous women and men, in addition to other groups whose historical and social dynamics of oppression prevail. For the Afro-Brazilian philosopher Djamila Ribeiro,

Relative to white women, there has been a breakthrough, many of them already conquered space and are recognized in their fields. But, regarding to black women, we still have a long way to go to combat what black feminists call epistemicide, the murder of our epistemes, as if black women don't produce knowledge. There is much knowledge produced, but there is still a vision based in the male and the white. (Ribeiro, 2016, her emphasis). ${ }^{1}$

Another important fact to be considered is how the work of translation is linked to a defined linguistic ("Who can speak?") and interpretive ("Who can read and interpret?") community, relating irremediably to linguistic policies (Hill-Collins \& Silva-Reis, 2019):

\begin{abstract}
A linguistic community is often seen as a site of social equality where speaking a shared language ostensibly fosters similar values, ideas and a common worldview. [...] In contrast, my sense of an interpretive community makes power relations more central to the act of communication and translation. Power relations within an interpretive community regulate who gets to speak, who is listened to and what knowledge comes to represent that community to outsiders. Power relations shape who is silenced and who is heard. (Hill-Collins \& Silva-Reis, 2019, pp. 222-223, their emphasis).
\end{abstract}

The constitution of these interpretative communities is linked to the formation of power relations: what the worldviews are, how they are interpreted, how they are explained to us, and so on. Therefore, the validation of different knowledge-making processes is formed. In addition, this fact is directly related to the formation of cultural identity of social subjects. According to Lélia Gonzalez, there is a process of determining the speech relations regarding non-dominant groups in Brazilian society:

Women and non-whites have been spoken of, defined and classified by an ideological system of domination which makes infants of us. By being placed in an inferior position within a

1 Personal communication. February 25, 2016. Interview: Brazilian Black feminist philosopher Djamila Ribeiro on intersectionality and the Black feminist movement. 
hierarchy, our humanity is erased because we are denied the right to be subjects, not only of our own discourse, but of our own history. This is characteristic of a patriarchal-racist system (Gonzalez, 1988, n.d., her emphasis).

The problems considered to be present in all these processes - epistemicide, and so on - are determined by broader social phenomena and could change the perspective of a political social order, if there were sufficient instruments for dialogue between dissimilar linguistic and interpretive communities. In addition, translation can incorporate structural political functions and activities for the exercise of changing epistemological perspectives.

The policies that involve the translation of certain epistemologies are not randomly defined, but their elaborations consist of verifiable historical-social elements outside the restricted field of the translational exercise. This is because translation, as an exercise of knowledge and as a practice of contact and interaction with dissimilar ideas and worldviews, is part of a broader system that encompasses social practices and, therefore, the traits inherent to their relationships. An example of this process is that of academic training at a global level. By English being considered a socially dominant language, the impact of intellectual production in other languages will be different (Hill-Collins \& Silva-Reis, 2019).

Postcolonial cultural theorists such as Gayatri Spivak and Tejaswini Niranjana, Susan Bassnett and Harish Trivedi speak out against the prominence given to English: a language of ex-colonizers, whereby translations into this language fail to translate the difference of the view of other languages and more so the language of the ex-colonized, because the translator over-adapts the text to the English culture, effacing, at different levels, elements of the source culture. Niranjana (1992, p. 2) affirms: "Translation as a practice shapes, and takes shape within, the asymmetrical relations of power that operate under colonialism". Bassnett \& Trivedi (1999, p. 13) consider that power relationships unfold in the unequal struggle of various local languages against "the one master-language of our postcolonial world, English".

With the 'Cultural turn' in Ts in the 1980s, propelled by the works of André Lefevere, Susan Bassnett, Lawrence Venuti, and others, translation theorists acknowledged and insisted that translation is not merely about linguistic equivalence and fidelity, but that it is also about questions such as culture, identity, history, ideology, and that greater significance should be given to these issues. Thus, the transformations that characterized the cultural turn centered on the view that text is embedded in a network of cultural ideological signs in both the source and target cultures.

The cultural translation theorists aforementioned consider translation not as being primarily about language in a purely linguistic sense or the mechanical conversion of lexical units between languages, but as a form of transfer, with language representing an expression and repertory of the cultures involved (Lefevere, 2004). For them, translation cannot be an isolated activity, as there is always a context in which it takes place, a history from which text is constructed and another one into which the text is transferred (Bassnett \& Lefevere, 1990).

Lefevere (1992) and others propound that translation is manipulation. The author initially uses the term refraction to refer to the adaption of texts into a new audience of readers in the target culture for the purpose of influencing how the work is read and interpreted. The notion of refraction was later developed 
into the concept of rewriting, which envisages translations as "created or projected images" of the original source texts Lefevere (1992). In this conception, texts are seen as being translated within an imposed ideological framework that ensures that they function as intended in a given society.

In our understanding of the concept of "rewriting", it refers to the ideological and poetological aspects when the translation is conforming to or rebelling against the dominant ideology and poetics. In this paper, we intend to observe whether the translations of the novels selected for study conform to or rebel against the expected literary conventions of the hegemonic English language.

Lefevere (2004) also propounds the concept of patronage, whereby he identifies within the general literary system, a focus on maintaining an asymmetrical balance of power, rather than the use of translation to merely convey meaning. The author envisages relations of power that become a part of the entire translation process. He suggests that such relations determine which texts are selected for translation, which guidelines are chosen to govern the procedure of translation, as well as what position the translated text occupies in the target culture, and such interests point to those in charge of commissioning and translating the work.

The author shows that, with the interests of the ruling group in mind, it is not uncommon for texts to be rewritten to adapt to ideological positions. In tandem with Lefevere's view, Bassnett looks at the heightened presence of translators, whose skills, she believes, can no longer be reduced to linguistic competence; the conceptions of rewriting and manipulation positions them at the centre of mediations pertaining to power and the order of social systems (Bassnett \& Lefevere, 1990).
Lefevere's work in Ts developed out of his close ties also with polysystem theory (Even-Zohar, 2012). The Israeli scholar Itamar Even-Zohar, from the 1970s, developed the theory, looking at the way in which translated literature operates as a system. His perspective is that translated literature works in a system in itself with regards to the way the target language culture selects works for translation, as well as to the way translation norms, behavior and policies are influenced by other co-systems. Even-Zohar $(2005$, p . 3) defines polysystem as "a multiple system, a system of various systems which intersect with each other and partly overlap, using concurrently different options, yet functioning as one structured whole, whose members are interdependent".

Polysytem theory, then, entails the interaction and (re)positioning of the multiple systems, a process that occurs in a dynamic hierarchy and that is transformed according to the historical moment (Even-Zohar, 2012). The process of transformation suggests a constant state of flux and competition, which means that the position of translated literature is not fixed.

As Even-Zohar explains, translated literature may occupy a primary position in the polysystem when it has major influence over the central system and contributes to transforming the conventional forms of the target system. In other cases, when translated literature assumes a secondary position, it represents a peripheral system within the polysystem, because it has no major influence over the central system and becomes a conservative element, conforming to the literary aspects of the target system.

Further on in Even-Zohar's conception, it is affirmed that the position occupied by translated literature in the polysystem may condition the translation strategy employed by the 
translator: if the position is primary, translators feel less obliged to conform to target literature models and may contribute to breaking conventions in the that literary norm. On the other hand, if translated literature is secondary, it is more common for translators to use existing target-culture models for the TT.

Within the broad literary field, one could say that translations of Caribbean and Latin American Black female authorship, seen as Third World literature operate inside the polysystem of Western literary canons as peripheral to traditional literature of the ex-colonizer. Bassnett and Trivedi (1999) identify a marginalization of Third World literary translations, in which Europe becomes the great original and the colonies are thus seen as copies. Nevertheless, in our perspective, Third World literary translations may be representative of defiance and rebellion to the hegemonic traditional literature and may contribute to transformations of the hegemonic literature.

Comparatively understanding the historical and social experiences of colonization in the Americas, or the Black Atlantic (Gilroy, 1993), Denise Carrascosa defends the theory that the task of translation would emerge due to its political character, articulating its rhetorical potential and its subversive impact. For her,

translation, therefore, emerges in the Black Atlantic as a political task in the Spivakian sense of strong work with language as an agent that produces identity, subalternity and, at the same time, in its rhetorical dimension, as a potential generator of subversive dissemination (Carrascosa, 2016, p. 66, our translation).

A critical political translation of Black female authorship from the Caribbean and Latin American contexts demands a critical awareness of the historical colonial constitution of the Black female subject, as well as the male/ female binarity demarcated in language (Kilomba, 2019). Such an awareness makes it possible for the translation enterprise to contribute towards pushing forward a more critically reflexive and just representation of the Black female subject, as proposed by Black female authorship.

Black female writings from the Caribbean and Latin America may be characterized as having a mestizo consciousness, a concept developed by the chicana intellectual Glória Anzaldúa (1987). Her conception of the mestizo consciousness points us to a symbolic border space where there is the transference and sharing of cultural values and the construction of mixed identities, and where the female woman of color may conquer and construct a voice among different interactive cultures. It involves the crossing of cultural borders and the creation of a fluid, heterogeneous space that allows subjects from different perspectives and backgrounds, subjects who speak different languages, to come in contact and reach a level of certain harmonious understanding.

In our interpretation, Black female literature is representative of Anzaldúa's conception of the mestizo consciousness, as it constructs a plural diverse universe in which the Black female subject moves away from the position of object to subject, and becomes politically aware of her oppressive condition, as well as empowered to struggle for the transformation of that reality. In this perspective, we consider that the novels selected for discussion in this paper constitute a dimension that characterizes the mestizo consciousness, as, having their experiences mediated by the coloniality of gender and race within their patriarchal racialized society, the protagonists gradually gain strength to begin overcoming the oppression they face.

In our perspective, the novels demand translations that are engaged in contributing to 
giving visibility to the Black female subject. In partnership with the Black female author, such translation would seek to empower the Black female subject by crossing historically rigid borders, breaking paradigms and deconstructing monolithic, mono-logical ways of representing women and their cultures in the Caribbean and Latin America. Such translation could be characterized as a social institution, i.e., as mestizo translation.

The idea of translation as a social institution is close to what Dyhorrani Beira (2017) evaluates of translation as mestizo practice, recovering the theory of the poétique de la Relation (Édouard Glissant, 1990). For her, the act of translating involves relational steps, which can be assimilated to the constitutions of multiple identities, that is, "a society/identity open to the various influences of the world, thus placing all peoples in contact or in Relation" (Beira, 2017, p. 190, our translation). In this sense, for us, mestizo translating means putting dissimilar peoples and communities in relation.

The approach of Lawrence Venuti on the practice of translation may contribute to our perspective in constructing a case for what we denominate as mestizo translation. His focus is on the invisibility of translators and he discusses two practices of translation that may serve the objectives of this paper, as they may contribute to the discussion on the in/visibility of Black female authorship. The practices are domestication and foreignization, and they are concerned with the translation method.

For Venuti (1998, 2008), domestication is related to the hegemonic British and American translation culture, in which translations are done to adhere to the literary canons of those cultures. We identify here a juxtaposition of Venuti's view with that of the postcolonial theorists aforementioned, such as Spivak and
Niranjana, who warn against the cultural effects of the differential in power relations between colony and ex-colony.

Venuti speaks out against the translation practice of domestication, as it involves "an ethnocentric reduction of the foreign text to receiving cultural values", translating in a fluent, "invisible" style so as to reduce the foreignness of the тт (Venuti, 2008, p. 15). On the other hand, foreignization refers to the development of a translation method that values the non-dominant culture, that is aligned with the literary and cultural elements of the foreign text. It involves a close adherence to the ST structure and syntax.

Venuti (2008, p. 15-16) considers foreignizing practices to be a "highly desirable [...] strategic cultural intervention" as they aim at "send[ing] the reader abroad" by making the receiving culture aware of the linguistic and cultural difference inherent in the foreign text. This is to be achieved by a non-fluent, estranging or heterogeneous translation style with the purpose of highlighting the foreign identity of the ST. As such, it may be possible to counter the unequal and violently domesticating cultural values of the English-language culture (Venuti, 2008, p. 16).

One can observe a political and ethical dimension related to practices of domestication and foreignization that involve the in/visibility of the sT culture in relation to the hegemonic English cultures. As Venuti points out, the terms domestication and foreignization indicate fundamentally ethical attitudes towards a foreign text and culture, ethical effects produced by the choice of a text for translation and by the strategy devised to translate it, whereas terms like fluency and resistancy indicate fundamentally discursive features of translation strategies in relation to the reader's cognitive processing (Venuti, 2008, p. 19). 
It is important for us to look briefly at the conceptions of translation strategies. In the perspective of Luc van Doorslaer (2007), a strategy, in the technical sense is an overall orientation of the translator, either towards free or literal translation, i.e, towards the TT or ST, in other words, towards domestication or foreignization: if the translator adheres to the literary aspects of the target text, the strategy points to being free; if the translator adheres to the literary aspects of the source text, the strategy is, more than likely, literal. The free or literal notion of translation strategy is also shared by Jean-Paul Vinay and Jean Darbelnet (1995), who use the terms oblique translation and direct translation, respectively.

Going back to Venuti, he recognizes certain limitation related to the notions of domestication and foreignization: some degree of domestication is unavoidable as the translation of a sT needs to be intelligible for a receiving culture. In our analysis of the novels we intend to look at possible means by which the translators made an effort to create a certain level of balance between the foreignization of the text and making the text intelligible in the target culture, if such is the case.

Venuti's foreignizing practice of translation is similar to what we understand as a mestizo practice of translation relating specifically to Black female writing. A mestizo translation of Black female authorship would be a kind if translation that finds a balance between giving visibility to the sT culture and making the text intelligible in the target culture. It is a kind of translation that is non-fluent, estranging, heterogenous, demonstrative of resistance (Venuti, 2008) to the hegemonic English language and culture. It involves creating a space in which dissimilar peoples and communities are put in relation, and in such a space, the Black female subjectivity is given visibility, instead of being obscured, as is common in traditional Eurocentric literature and translation.

453

\section{Methodology}

As the aim of this paper is to discuss the political agency of the translation of Afro-Caribbean and Latin American female authorship with focus on describing the process and product, it is important to draw on Gideon Toury's perspective of descriptive translation. His work in developing Descriptive Translation Studies (1995, thereby, DTS) as a subfield in TS contributed to transforming the perspective of the field from regarding translation as merely attempting to reproduce meanings through linguistic equivalence, to seeing it as the constructing of a text within a given socio-cultural context. Toury developed a target-oriented perspective in his DTS, which was a reaction to normative, prescriptive, and synchronic theoretical frameworks, and has aimed at reaching a general translation approach.

In his perspective, translations are the "facts of the culture which hosts them" translations and their translators cannot be thought separate from the culture in which they exist (Toury, 1995, p. 24). His approach deals with a group of relations which control the translation activity rather than focusing only on the aspect of equivalence. He considers equivalence on a level that is descriptive and functional, which differs from the traditional, invariant, ideal and prescriptive concept of equivalence.

In individual studies, to carry out a description of the translation product and process, taking into consideration the wider role of the sociocultural system, Toury (1995) suggests the following three-phase methodology for analysis: (i) look at the text within the target culture system and analyze its significance, observing whether it is adequate or acceptable; (ii) develop 
a textual analysis of the ST and the TT so as to identify relationships between corresponding segments or coupled pairs in the two texts, observing word choices and translation shifts (obligatory and non-obligatory); (iii) construct argument related to the patterns identified in the two texts, as this may contribute to reconstructing the process of translation for this STTT pair.

It is important for us to take into consideration also the work done "On describing translations" by José Lambert \& Hendrik van Gorp (1985). Having been influenced by Even-Zohar's and Toury's early work, they propose a methodology for the description of relations between the sт and тT literary systems (Lambert \& van Gorp, 1985, pp. 52-53):

1. Preliminary data: observe the title and title page for presence or absence of genre indication, the author's name, translator's name, and so on; identify metatexts on title page, in preface, in footnotes, [...].

2. Macro-level: look at the division of the text (in chapters), titles of chapters, internal narrative structure, authorial comment [...].

3. Micro-level: identify shifts in translation; look at the selection of words, dominant grammatical patterns, forms of speech reproduction (direct, indirect, free indirect speech), narrative, perspective and point of view, [...].

4. Systemic context: point out oppositions between micro- and macro-levels and between text and theory [norms, models], intertextual relations [other translations and creative works] [...].

In our perspective, Lambert \& Gorp's model complements Toury's model. As one may observe, their model makes it possible to carry out a more detailed description of the translation product and process in general.

Due to the nature of this research, it was necessary for us to select parts of Toury's and Lambert \& Gorp's model, as well as include
Venuti's perspective on translation practice, in order to carry out our analyses. Thus, the aspects we selected for description include: (1) a textual analysis of the тт: the title and title page for presence or absence of the author's name, translator's name; metatexts whether they are in the text or separate to identify the translators' comments (Lambert \& van Gorp, 1985); (2) a textual analysis of the sT and the тт: relationships between corresponding segments or coupled pairs (Toury, 1995) in the two texts, observing word choices related principally to the category of race and gender.

With the information gathered from items (1) and (2) above, we constructed arguments regarding the translation product, observing whether it is non-fluent, estranging, heterogenous or fluent, homogenous, domesticating (Venuti, 1998). We also constructed arguments regarding the translation process, specifically in relation to decisions made and the translation strategy employed.

\section{Discussion on the translation product and process}

\subsection{The Women of Tijucopapo}

The University of Nebraska Press published The women of Tijucopapo in 1994. The front cover of the book bears only the title in English - literally translated from the original As mulheres de Tijucopapo-along with Felinto's name, which points the reader directly to Felinto as sole author. We think that this information is misleading to a certain level, as it suggests that the book is entirely from Felinto's perspective. It contributes to a certain invisibility of the translator's voice, whose name, Irene Matthews, first appears on the title page, along with Felinto's name, the title of the English version, as well as the title in Portuguese. 
The title page also points the reader to an afterword written by Matthews, in which she briefly presents her interpretation of Felinto's novel. In our interpretation, this reference to the afterword could entice the reader to go directly to Matthew's interpretation before the actual reading of the novel. In the afterword, as we discuss further, Matthews contextualizes the novel, explaining cultural elements that, at first glance, might seem difficult for the reader from the target culture to understand. As such, it seems to us that the afterword facilitates the interpretation of the novel for this kind of reader. This represents a sign of domestication of the novel, an aspect that we observe further on.

The next page in the novel, which bears information on its edition and publication, shows that the book comes under the edition of Latin American Women Writers, through a team of academic editors from Colombia University, the University of California at Berkeley, and Stanford University; and it was published by the University of Nebraska Press. This suggests that the translation project and publication of the version in English involved a conjoint effort from members of different universities, except that the process of translation was carried out integrally by Matthews. Such an effort initially suggests that the project had a support network from the American academia.

Nevertheless, the support network seems to have departed from a plural perspective, because, further on, in the "Note on the translation", Matthews points out that, during the translation activity, she was able to visit Felinto in Brazil, through funding from the National Endowment for the Humanities and by the accompaniment of members from a research group from the department of Spanish and Portuguese at the University of Maryland.
She also acknowledges research support from Northern Arizona University. We consider relevant the involvement of the Spanish and Portuguese department in the project, as such aspects could have had profound impact in the construction of the general Latin American perspective of the translation.

The page of contents tells us that the book includes: "Note on the translation", the translated text itself under the heading "The Women of Tijucopapo", "Glossary" and "Afterword". In the "Note on the translation", other than the initial circumstances of the project aforementioned, Matthews discusses some of the challenges she faced in translating the novel, and the strategies she employed to overcome them. She describes the Portuguese text as containing a "harsh message and tone", and that she made an effort to carry over into the English version the "short, sharp sentences" of Felinto's writing, as well as the book's "elliptical structure".

Such a structure of which Matthews speaks, in our reading, refers also to the repetition of certain phrases in the original version. In our interpretation, such repetition by the young adult narrator-protagonist, Rísia, - who travels on foot from the urbanized city of São Paulo to get to the fictitious rural place of her mother's birth, Tijucopapo, located in the state of Pernambuco in the Northeastern region of Brazil - points to her constant re-visit to scathing moments in her childhood, as she attempts to get beyond them. Rísia's story, set in the 1970's, with continuous flashbacks to the past, seems to a singular one in virtue of her gender, class, and racial background. On that journey, becoming aware of her own cruelty towards a classmate is one of the first scathing memories for Rísia that she has to face up to. The narrator re-describes or re-mentions, at different moments in the narrative, the reaction of her 
Portuguese

Dona Penha sentou-se pasmada diante de mim a carta na mão, Luciana ao lado dela, Luciana assoando [sic] um resto de choro num lenço amarrotado. Foi o dia de maior vergonha de minha vida (Felinto, 1982 p. 29).

classmate Luciana and her teacher, who are appalled by a verbally abusive letter that she wrote to her classmate, as seen in Example 1.

The repetition of this event is duly expressed in the English version, as seen in the segment above: the translation is direct (Vinay \& Darbelnet, 1995), heterogenous (Venuti, 1998, 2008), without evidences of shifts; the structure of the sentences maintains short phrases separated by commas, as in the Portuguese text.

We also identify the repetition in the Portuguese text as part of the aesthetics that represents the childish realm of the protagonist: she keeps revisiting childhood moments in her mind, as a way of constructing self-empowerment. It is as if the narrator is telling us that the child within her is still very much alive and is still quite disgruntled. With regards to that, Matthews seems to regard the language of the Portuguese text as being "colloquial, personal, sometimes childlike" (Felinto \& Matthews, 1994, p. viii). She affirms that she tried not to lose the "obsessively immature and reiterative nature of the search into and out of the truth of the self" (p. viii).

Matthews' assertion may be initially perceived as a kind of diminution of Felinto's aesthetics. However, she seems to have made real effort

\section{English}

Miss Penha sat down astonished in front of me, the letter in her hand, Luciana by her side, Luciana wiping the end of a sob, from her nose with a wrinkled handkerchief. It was the most shameful day in my life (Felinto \& Matthews, 1994, p. 16).

to maintain such aesthetics in the translation of the text. In our perspective, the "childlike" language of the Portuguese text and its maintenance in the English version is important as it reinforces the element of the interior monologue that dominates the narrative: as an oppressed Black female subject, initially, Rísia cannot speak to the oppressor (Spivak, 1988); she speaks to herself, which represents her processing of the past and the present, as a way of finding strength to grow and overcoming the pain of the oppression she has faced and still faces.

Matthews also affirms that, during the translation process, in cases where she had doubts regarding the accurateness of words due to Felinto's crafty and spasmodic writing, she chose to translate words in a literal sense that might seem "awkward" (Felinto \& Matthews, 1994, viii) in English, rather than choosing words in English that would not draw attention, but would give inadequate meaning. We identify the translation of the place of birth of the protagonist as an example of a kind of "awkwardness" of which the translator speaks (see Example 2).

We observe a direct translation (Vinay \& Darbelnet, 1995), in which the hyphen is maintained, "moon-town" for "vila-lua", which is

Example 2

Portuguese

A Poti é a vila-lua onde nasci. (Felinto, 1982, p. 55).

\section{English}

Poti is the moon-town where I was born. (Felinto \& Matthews, 1994, p. 43). 
a word that does not commonly appear in the usage of the English language, but however, is intelligible in the target culture.

It is important for us to point out that since the Portuguese text comes to us from a specific region in Brazil, the Northeastern region, it includes words that are specific to the region and that might seem awkward to Brazilian readers from other regions. Moreover, since the author constructs a fictitious town to which the narrator is headed, the text also includes words that might be unusual even to readers from the Northeastern region, such as those shown in Example 3.

Example 3

Portuguese

[...] eu montaria cavalos e sairia desembestada.

(Felinto, 1982, p. 127).

Instead of the word desembestada, perhaps a word that is more commonly intelligible in Brazil is desenfreada. We notice that in the translation, the choice of the translator is the word "uncurbed", which is less intelligible in English language settings that words such as "unchecked" "unrestrained", words that are more commonly used. As such, in our perspective, the translator mirrors the logic of the choice of words of the author of the text: selecting words that create certain level of awkwardness or sentiment of estrangement (Venuti, 1998, 2008) in the reader.

In our reading of the novel in Portuguese, the spasmodic or disconnectedness of which Matthews speaks to describe Felinto's writing makes up the author's aesthetics, which carries profound meaning to the text: it portrays the perplexity, uncertainty, turbulence of Rísia's reality, that

\section{English}

[...] I could ride horses and take-off uncurbed. (Felinto \& Matthews, 1994, p. 112).

Felinto wishes to inflict on the reader through a level of frustration in the reading of the text. It is possible to find constant abrupt changes in the narrator's chain of thought in both the Portuguese and English texts (Example 4).

The translation proves to be direct (Vinay \& Darbelnet, 1995), following the sequence and broken logic of the first version. This kind of writing is distinct from traditional literature related both to the sT and the тT.

The perplexity, uncertainty and ambivalent feelings within which the protagonist oscillates, in consequence of her turbulent, unstable reality is also expressed through a language that is not "of peace". This expression is taken from a poem, "Da Paz" [Of Peace], written by Brazilian Marcelino Freire (2013), in which a Black mother from a favela, who has lost her

\section{Example 4}

Portuguese

Vou dizer sobre quando e como foi que minha mãe nasceu, antes que seja tarde. Nema e Ruth eram irmãs e eram pessoas que me levavam para passear. Na casa de Lita, no fundo da casa da Lita, armava-se uma goiabeira. Julieta tinha tudo de gente rica. Titia bebe álcool puro em copo. Irmã Naninha [...]. Irmã Lurdes é crente [...]. Minha avó deu minha mãe numa noite de luar. A Poti é a vila-lua onde nasci. Eu que vôo nos aviões de Varig (Felinto, 1982, p.55).

\section{English}

I'm going to talk about how and when it was that my mother was born, before it gets too late. Nema and Ruth were sisters and they were the persons who took me out on walks. In Lita's house, at the back of Lita's house stood a guava tree. Julieta had everything that rich people have. Auntie drinks glassfuls of pure alcohol. Sister Naninha [...]. Sister Lourdes is a believer [...]. My grandmother gave my mother away on a moonlight. Poti is the moon-town where I was born. I, who fly in Varig's planes (Felinto \& Matthews, 1994, p. 43). 
Example 5

Portuguese

Me vem barro na boca, gosto vermelho, cuspo farinha, os dentes rangem. Eu tinha cinco anos e comia terra e cagava lombriga abestalhada, os olhos arregalados como os de bota, sem que nada me impedisse, porém de correr em disparada no outro dia e deslizar de cima a baixo do morro de terra, me embolando me enrolando, comendo, cuspindo e cagando e dizendo aos ventos que dissessem a eles: "Vão à merda das minhas lombrigas, papai e mamãe, vocês que se intrigam e me intrigam nas suas intrigas me fazendo chorar tanto assim (Felinto, 1982, p. 15, our emphasis).

son to police violence, says that "Peace" is a luxury. In our interpretation of the poem, "Peace" is constructed as a form of silencing of the oppressed, and to resist, therefore, the oppressed cannot be "of peace"; he/she must face the oppressor with brute force, intensity.

It is in this sense that Felinto's language is violent, disturbing, provocative, "hard-core", it is not "of peace". It is a language of struggle and resistance (Example 5).

At this stage in Rísia's memory, we see a childlike language that expresses defiance and intensity, which is also firmly expressed in Matthew's version. The translation seems to us to be direct (Vinay \& Darbelnet, 1995), with insignificant shifts: in "eyes bulging" for "olhos arregalados" we see the gerund used in place of the past participle. We say the shift is insignificant as it does not take away from the meaning of phrase. Also, in our perspective, the vocabulary proves to be precise in terms
English

My mouth is filled with dirt, it tastes of red, I spit grit, I grind my teeth. I was five years old and I was eating dirt and shitting round worms like crazy, my eyes bulging out like a dolphin's; that didn't stop me from stampeding out the next day, however, and sliding from the top to the bottom of the mound dirt, wrapping myself in dirt, and rolling in it, and eating and spitting, and shitting, and bawling into the four winds to go tell them: "You go to hell and take my worms with you, papa and mama, and take your quarreling and your quarreling about me and your quarrels that make me cry so hard (Felinto \& Matthews, 1994, p. 2, our emphasis).

of the intensity of the event described: "grind" for "rangem", etc. Similar to the sT, one could say that the translation creates an estranging (Venuti, 1998, 2008) effect.

As the novel unfolds, we see Rísia developing into a woman. Still through her memory, we recognize that her childlike defiance turns into unmoving struggle that, again, is not "of peace". She wishes to create a "War code" (Felinto, 1982, p. 18) through a foreign language, so that her truths could become known around the world - "os fatos seriam mais mundiais" (p. 18), and, as such, in our interpretation, women around the world could build a chain of struggle by sharing their stories, as well. Then, women's struggle would move from the status of being personal to being public, political. One could say that Rísia's desire is being accomplished through the political agency of Matthews, who has translated and published Rísia's story in foreign land. And Risia's desire is duly expressed in the English version (in Example 6).

\author{
Example 6 \\ Portuguese \\ Me disseram que vivo é em guerra. Em pé de guerra. \\ E vivo mesmo, e acrescento que vivo em batalha, em \\ bombardeio, em choque. E só vou conseguir sossegar \\ quando matar um. É que quando eu era pequena \\ alimentei durante todo o tempo a ideia de matar o \\ meu pai. Não matei. Não o matarei mais. Mas ficou à \\ vontade, essa de matar um (Felinto, 1982, p. 18).
}

\section{English}

They told me I live as if I were at war. On the warpath And I definitely do, and l'd add that live in combat, under bomb attack, in conflict. And I won't calm down till I kill someone. When I was a little girl, I always clung on to the idea that I would kill my father. I didn't kill him. I wouldn' $t$ kill him now. But the desire to kill someone remained (Felinto \& Matthews, 1994, p. 5). 
We observe once more that the translation is direct (Vinay \& Darbelnet, 1995), with insignificant obligatory shifts: for instance, the use of the phrasal verb "clung on to" for "alimentei" adds prepositions to the sentence.

Felinto's language of resistance cannot be a monolithic, mono-logical one. It is a language of plurality. It decentralizes the language of the colonizer, through plurilingualism. As we have mentioned, it is a language that by presenting unusual words in the source culture, causes estrangement (Venuti, 1998, 2008) in the Brazilian reader in terms of the logic of the Portuguese language. We have also pointed out that such aspect is replicated in the target text.

Thus, in looking at Felinto's heterogenous language in another aspect, it is possible to find words in Tupi-Guarani in the Portuguese text. That language belongs to one group of the indigenous peoples in Brazil. "Poti" (Felinto, 1982 , p. 55) and "seriema" (ibid, p. 34), for instance, are Tupi words inserted in the narrative that invite the reader to dig deeper to find their meanings.

In the English version, these words do appear unformatted, not being set apart, like in the Portuguese version. However, the words appear in the Glossary at the end of book, in which Matthews explains these and other words, to facilitate the reading in English. Perhaps, that may implicate in the translator giving too much information to the reader. Nevertheless, as the Glossary is separated from the text and comes at the end of the novel, we would not say that Matthews' intention is to domesticate the text. In fact, we believe that, this is where she establishes a certain level of balance between the foreignization of the text and making the text intelligible in the target culture.
One of the relevant issues to be reflected on in looking at the critical enterprise of the translation is the constitution of the Black identity, and more specifically, the Black female subject. In the Portuguese text, we realize that the constitution of Blackness is a question that Rísia grapples with, as she goes through a painful retrospective process of growth.

The constitution of Blackness is very much a part of Rísia's search for the understanding of origins, her ancestry. In her narrative of that past, we notice that, still in her childish unawareness, she does not demarcate clear cut words to express Black identity of people in opposition to the literal "darkness" of things. More specifically, she uses words like "preta/o", "negra/o", "escura/o" interchangeably for things; and "negra/o" or "preta/o" for people.

The Black community in the Brazilian context commonly uses "negra/o" or "morena/o" for Black people, while "preta/o" may have both positive and negative connotations, depending on the context. A spouse might affectionately call his or her partner "preta/o"; a parent may lovingly call a child "pretinha/o". On the other hand, in contexts that are marked by racial tensions, "preta/o" is more commonly used in an offensive way, rather than "negra/o".

In the Portuguese text, Rísia's interchangeable use of "preta/o", "negra/o" regardless of the context reinforces her grappling with trying to understand her Black identity in her process of growth (Example 7).

In the first excerpt in Portuguese above, Rísia discusses the circumstances of the birth of her mother and her grandmother's struggle. In such desperate conditions described, in which she sees her grandmother crippled by pregnancy, the words "preto" and "negra" are used in 


Portuguese
Era 1935, todos os raios da lua escapuliam do céu
preto alumiando o caminho [...]. Minha avó nem
sequer açoitava o bicho; vinha pachorrenta [...].
Minha vó era tão negra que se arrastava. Ela levava
a minha mãe, a que seria dada (Felinto, p. 20, our
emphasis)
Todas as ideias me remetem às mulheres de
Tijucopapo [...]. Também sei desenhar. Desenhar que
estourou uma bomba de lama que se bipartiu em
mim em seringa nos olhos, o meu choro e em minha
imãe na bolsa que parte. E nasci eu. Sou feita de lama
(Felinto, 1982, p. 56).

negative connotations. In the second excerpt in Portuguese, there is the word "negra" is associated with "lama imunda". In our interpretation, in her early retrospective thought, Rísia makes an association with dirtiness and being Black: this seems to be an interiorization of the oppression and inferiority that is imposed on her as a child.

Nevertheless, in our reading, it is possible to identify in Rísia's thoughts seeds of resignification of Blackness, as she approaches the final stages of her growth. When Rísia finally arrives in Tijucapo, after having travelled - not coincidentally - for nine months, the word Black is associated with the possibility of freedom and overcoming. "The black earth" of which Rísia makes a lot of references to throughout the narrative is now used in a positive connotation: it is associated with freedom, as she rides horses freely on that earth, "nesse lugar onde eu montaria cavalos e sairia desembestada ao encontro da explicação que talvez esteja no onde a praia encontra a lama, o negro tijuco" (Felinto, 1982, p. 127).

Taking into consideration what we have argued thus far, Matthew's translation points to an orientation towards the sT, a foreignization (Venuti, 1998, 2008) of the text; the transla-

\section{English}

It was 1935, all the rays of the moon stole from the black sky along a path through the hills lighting the way [...]. My grandmother was so black that she crawled. She was bringing my mother, who was to be given away (Felinto \& Matthews, 1994, p. 7, our emphasis)

Every thought reminds me of the women of Tijucopapo [...] I know how to draw, too. How to draw a mud bomb that bursts into two around me and spayed into my eyes, my tears, and into my mother around the birth sack. And I was born. I am made of filthy mud. [...] I am made of mud that is black with earth (Felinto \& Matthews, 1994, p. 45).

tion strategy is literal. To the reader from the target culture, the text will seem non-fluent, estranging and heterogenous (Venuti, 1998, 2008). This aspect of the translation is representative of Felinto's style of writing, which is carried over into the target text: an evident desired effect, on the part of the translator.

\subsection{Who slashed Celanire's throat?}

The English version of Célanire cou-coupé (Editions Robert Laffont, 2000), a novel by Guadeloupian Maryse Condé, received the title Who slashed Celanire's throat? and was published by the New Yorker editorial group Atria Books in 2004 , four years after the original text was published in French. The translator who signs this version is the author's spouse, Richard Philcox. The fact that Philcox establishes a close relationship with the author means, for the comparative scientific purposes, only a possibility of interpretation regarding the dialogue process inherent to the translation dynamics, which is revealed by the participation of Maryse Condé in the translation stages. The detail that there is a certain participation of the author or not can vary depending on the translation process, however, what we describe mainly concerns certain translation strategies and certain paratextual elements: title, presentation of the translator, preface, translation notes etc. 
A first detail to reflect on in the English version of the novel is that there are no translation notes, preface or afterword containing any description of the translation process or strategies, verifiable when comparing sт and тт or using interviews with the translator.

Initially looking at the title, we have a semantic-communicative change: Célanire cou-coupé becomes Who slashed Celanire Throat? Between the transitions from a declarative sentence, in French, to an interrogative one, in English, the focus on the name of the character Célanire a métisse guadeloupéenne - changes its position, giving rise to questions about the authorship of the cut on her neck. In a more restricted sense, the apparent attention to the female character is lost due to an anonymous authorial focus. In part, this could be explained by the plot lines. Célanire had been abandoned by her family and should be sacrificed. The sacrifice attempt was unsuccessful because a doctor decides to adopt her after treating her wounds. With that, the scars remain and the child grows up cultivating a desire for revenge. The mystery about her history is notorious in the novel, and for that reason, it would explain the interrogative proposition in the English version. However, there are other aspects to consider. The novel takes place in a colonial setting - chronologically and geographically. The character's desire for revenge indicates a certain tone of approximation between her story and the history of colonial violence, whose wounds are difficult to heal (Fanon, 1952). Another point that can be observed is that the word cou-coupe phonetically carries the syllabic repetition characteristic of a popular culture, as it also means a species of bird - Amadina fasciata - present mainly in sub-Saharan Africa.

The novel, subtitled Fantastic Tale, presents a narrative of four spatial plot plans: Ivory Coast, Cayenne, Guadeloupe, and Peru, between the years of the first decade of the $20^{\text {th }}$ century. For that fact, there is in Who slashed Celanire's throat? the constancy of words of African origin, expressions and words in Creole, and, finally, in Spanish. In the original text, in French, the author decided to add a glossary, containing brief explanations about words like yavogou, an honorary title, or brujas, witches. The text, imbued with hybrid elements, in the Antillean context, takes on its own meaning in relation to literary language. In the English version, Philcox demonstrates these words as they appear in the original text, differentiated only by the use of italics. It is noted, then, the use of non-English speaking origin words in italics, different from the strategic choice defined by the author in her original edition.

What is striking is the fact that there seem to be separate editorial and translation agreements for the original text, in French, and for

\section{Example 8}

French
Au loin, des lumières apparurent dont la vue sembla
leur donner des ailes aux talons: Adjame-Santey.
Le tipoye se mit à cahoter comme si les vagues
de l'océan le ballottaient. Malgré cela, Célanire
s'engourdit dans un demi-sommeil jusqu'à ce qu'un
brouhaha de voix surexcitées l'en tire. Une troupe de
askaris, comiques avec leurs jambes enroulées de
bandes de molleton et leurs chéchias de travers, avait
manqué renverser les porteurs. (Condé, 2000, p. 18).

\section{English}

Lights appeared in the distance, the sight of which seemed to put wings on their heels, and AdjameSantey come into view. The tipoye began to jolt as if buffeted by the ocean's waves. Indifferent to all this, Celanire sank into a semi-slumber until a commotion of excited voices awoke her. A troop of askaris, a comical sight with their legs swathed in strips of cotton fleece and tarbooshes askew, had almost collided with the porters. (Condé \& Philcox, 2004, p. 6, their emphasis). 
its English version. In Who slashed Celanire's Throat?, there is no glossary, nor explanatory notes, leaving the reader in charge of the semantic verification of words of African, Creole and Spanish-speaking origin.

When observing the description of the character Célanire, in the original text, we have the record shown in Example 9.

There is an assimilation between the color of the character and an apparent constant mourning - "comme un grand deuil" -, which is reconciled with her mood. There is, moreover, the assumption of their place of origin - "de la Guadeloupe or de la Martinique". The description of the character sometimes seems to be metaphorically supported by the description of the islands of origin and the configuration of this social, historical and, nonetheless, religious space. In this highlighted excerpt, we examine the strategies adopted during the translation process that contributed to mitigate or to insist on the features defined in the original text. Through this exemplified excerpt, we can identify the definition of a translation strategy for words that are certainly complex to be translated, especially those that refer to the Caribbean black linguistic community. The words nègre, noire, négresse and métisse can cause certain problems for different sociolinguistic groups. The Black community affectionately adopts them. When the non-black community receives and enunciates them, they can have other meanings and generate political discomfort. In Philcox's version, the solutions to the problem appear as "natives", "black", "dark skin" and "hybrid".

In an interview with researchers Doris Y. Kadish and Françoise Massardier-Kenney, in 1996, Richard Philcox portrays certain processes of translation of Maryse Condé's novels. Among them, he reveals that he judges, alongside the author, the translation of certain novels, trying to avoid possible mistakes. The example presented in this interview is the English version of the novel Ségou (1984, 1985), whose translation is signed by Barbara Bray - which, according to Philcox, makes some mistakes. When asked about possible considerable mistakes in the definition of words, he argues, "Africa's vocabulary was inaccurate. A pagne was translated as $G$-string, and l'hivernage was winter, and other such things" (Philcox, Kadish \& Massardier-Kenney, 1996, p. 750).

The definitions around the adoption of literal translation and the attempt to approach the text as fluently as possible ends up constituting what Venuti (2008) classifies as domestication. Regarding the case of the English version of

\section{Example 9}

French
Célanire Pinceau. Patronyme peu commun ! [...] Elle
ne parlait guère. Elle ne semblait pas curieuse, excitée
comme ses compagnes, impatientes de commencer
leur apostolat. En plus, sa couleur la mettait à part,
cette peau noire qui l'habillait comme un vêtement
de grand deuil. Elle n'était pas franchement négresse.
Plutôt métisse d'on ne savait combien de races.
[...]. D'où sortait-elle ? De la Guadeloupe ou de la
Martinique. Enfin, d'une de ces colonies qui n'ont de
français que le nom, habitées par des nègres baptisés,
qui font quand même bamboula, jurent comme
païens, battent le tambour et boivent des alcools forts.
(Condé, 2000, pp. 13-14)

\section{English}

Celanire Pinceau. A most unusual name! [...] She hardly spoke. She did not seem curious or excited like her traveling companions, who were eager to begin their missionary work. What's more, her color set her apart, that dark skin that clothed her like a garment of deep mourning. Her features were not strictly black - rather, a hybrid of goodness knows how many races [...] Where did she come from? From Guadeloupe or Martinique. Well, from one of those colonies that are only French by name, where the natives have been baptized yet still run wild, swear like heathens, beat the drum, and drink strong liquor. (Condé \& Philcox, 2004, pp. 1-2) 
Condé's novel, we could judge the pertinence of not making her text fluent enough to structurally modify the author's aesthetic proposal. However, it would also be appropriate to question whether there is even a glossary, or even a preface, containing any description of access to the text for English-speaking readers - different from the original text, in French. The Guadeloupian author "would say that it is not bad to make the reader work" (Philcox, Kadish \& Massardier-Kenney, 1996, p. 751).

Some excerpts from the novel can serve as an example of this translation strategy, which, on the one hand, retrieves words in non-hegemonic vernacular languages, and, on the other hand, requires the reader to search to understand their meanings (Example 10).

\section{Example 10}

\begin{tabular}{l|l} 
French & English \\
\hline Félix Koffi, le nouveau chrétien, qui à présent & Felix Koffi, the new Christian, who could now put \\
baragouinanit quelques mots de français, se précipita & together a few words of French, rushed toward her: \\
vers elle: & "Ça wa ben? Ça wa ben?" (Condé \& Philcox, 2004, p. \\
- Ce wa ben ? Ce wa ben ? (Condé, 2000, p. 56) & $46)$
\end{tabular}

Here, the expression "Ce wa ben?" comes from French expression "Ça va bien ?". In the English version, it remained as it was. For a francophone or francophile reader, the identification may be immediate, for others, not.
In the examples below, some words in Creole, such as "kwi de kwak", "gwo-ka", "poto-mitan", "nèg-kann", maintained as in the original (Examples 11, 12, and 13).

\section{Example 11}

\section{French}

Ses soins, ils les dispensait gratis ou presque : en échange, un peu de miel sauvage, une tranche de mérou, un agouti, des œufs de caret, un kwi de kwak faisaient son bonheur. (Condé, 2000, p. 101)

\section{English}

He meted out his treatment free of charge or almost, in exchange for the joy of a little wild honey, a slice of grouper, an agouti, turtle eggs, or a gourd of cassava kwak. Condé \& Philcox, 2004, p. 90)

\section{Example 12}

\begin{tabular}{|c|c|}
\hline French & English \\
\hline $\begin{array}{l}\text { L'assistance, déjà déconcertée par les airs de beguine, } \\
\text { se demanda si on allait se mettre à battre le ka. Elle } \\
\text { n'en crut pas ses oreilles quand Célanire, montée } \\
\text { en vitesse sur le podium, fit en phrases bien torunées } \\
\text { et bien senties un éloge de la culture traditionnelle. } \\
\text { Culture traditionnelle dont le gwo ka était le poto- } \\
\text { mitan. Pourquoi en avoir honte ainsi du créole, lang } \\
\text { manman-aw? (Condé, 2000, p. 145) }\end{array}$ & $\begin{array}{l}\text { The guests, already disconcerted by the beguines, } \\
\text { wondered if they were going to start beating the } \\
\text { gwo-ka drums. They could not believe their ears when } \\
\text { Celanire, who had leaped onto the podium, began } \\
\text { praising the merits of cultural traditions, of which the } \\
\text { gwo-ka drum was the poto-mitan, in an eloquent, } \\
\text { articulate speech. Why be ashamed of it? Why be } \\
\text { ashamed of Kréyol, our Patwa mother tongue? (Condé } \\
\text { \& Philcox, 2004, p. 134-135) }\end{array}$ \\
\hline
\end{tabular}

\section{Example 13}

\begin{tabular}{l|l} 
French & English \\
$\begin{array}{ll}\text { [...] n'avait pas abuse d'elle comme le premier nèg- } \\
\text { kann venu. (Condé, 2000, p. 149) }\end{array}$ & $\begin{array}{l}\text { [...] had taken advantage of her like the first uncouth } \\
\text { nèg kann to come along. (Condé \& Philcox, 2004, } \\
\text { p. 139) }\end{array}$
\end{tabular}


The glossary for the French version contains the following definitions: kwi, "calebasse évidée coupée en deux"; kwak, "granulés de manioc"; ka, gwo-ka tambour, "l'instrument roi" (Condé, 2000, p. 248). There is no mention in the glossary of poto-mitan. For nèg-kann, there is an explanatory note at the bottom of the page: "manant, homme sans éducation" (Condé, 2000, p. 149).

The case of the translation of Condé's novel is especially complex because it requires, at least, the articulation of aesthetic elements defined by the author that make her narratives part of the sociolinguistic composition of her place of origin - as Felinto's novel.

The maintenance of words in Creole, the emphasis in italics, the non-use of glossary or explanatory notes permeate the translation strategy and are related, in some way, to editorial policies. The relevance of these questions of editorial strategic choices has to do with the position defined by the author to refuse the opposition "colonial language/mother tongue" (Lappin-Fortin, 2013) interfered in her text. The aesthetic language of Condé "is not the language that can be understood in France, [but] a mixture between the language of a person born in Guadeloupe [...] with the sound of the different sounds of language, and my personal language" (Condé \& Barbour, 2006, p. 14). Her plurilinguistic aesthetic-literary trait also has to do with the place from which the novelist writes: the Antilles. Moreover, in the spectrum of the structural set of the novel, there is a relatively broad panorama of the stories surrounding the character Celanire, set in Ivory Coast, Cayenne, Guadeloupe and Peru. There are, therefore, marks of other identities - mestizos - in her text, which is not isolated from the prominent linguistic fabric of the regions figured in her novel. In that sense, a reason for a glossary in the French edition. It is in the interest of Condé's translator to safeguard the features that characterize her text geographically. So, in his words,

When people speak, we are very tempted to take a Jamaican dialect as equivalent, or even, since it is an American publisher, to take Black American English. It is a very big temptation to dive into black American when it comes to certain characters. As I am very interested in the language, I often have these expressions of slang and of Black-American language which one hears on television or around oneself. But I had to dismiss them because I felt that it did not correspond at all to the island of Guadeloupe (Philcox, Kadish \& Massardier-Kenney, 1996, p. 752, our translation).

In the case of the translation of Afro-Caribbean texts, the dispute concerns the transposition of a speech close to the editorial expectations of the target linguistic audience. That is to say, when the publisher sees in the group of African American readers a commercial possibility, the strategy is to correlate Caribbean French - spoken by a majority Black community - with Black American English. In this correlation of forces, the Caribbean French is mistakenly assimilated to the Black linguistic community of the United States - the publisher's country of origin and whose citizens make up the target audience. However, the translation strategy was, in this sense, based on the heterogeneity of Condé's text, seeking to define parameters that are not only linguistic, but political. In this sense, Philcox's translation strategy is literal.

Translation as a mestizo practice implies a critical position in relation to the translation exercise. That is to say, it should not be carried out specifically by a non-Western community, which may, at times, not have a critical political stance in the face of the relational action between the source texts and the translated 
texts. Therefore, mestizo translation cannot be apprehended strictly by the place from which it takes place.

What is expected as a question is the perception of the translator's stance in face of the nuances, the particularities and, above all, the impact, on the political-linguistic level, of the definition of the translation stzrategy. This is because, as many authors argue, translation becomes a tool for building political alliances between women from different linguistic communities.

\section{Conclusion}

In our overall observation of the English versions, it is possible to identify a partnership, on behalf of the translators, with the Portuguese and French texts: they walk hand in hand with the authors' proposal, portraying the gruesome reality through which the Black female protagonists undergo, in order to find a beam of hope to construct a positive identity.

Matthews' translation, which points to an orientation towards the ST, is affirmative of a critical enterprise/ political agency, as it mirrors the complex artistic maneuvers of Felinto's writing to give visibility to the painful reflections of the protagonist on her existence as a Black woman in an oppressive society that disenchants her.

The direct contact between Philcox and Condé made it possible, in an assimilable way, to raise awareness regarding the text by the Guadeloupian author, which shows itself, aesthetically and socially plural. As the translator defines his starting point, articulating mestizo and specific elements without disrupting the Sт according to the TT, we can identify his critical action in the face of editorial limitations or impositions.
Thinking in terms of the polysystem (Even-Zohar, 2012), we could say that Matthews' and Philcox' translation, as part of 'Third World' literature, represents a peripheral system, as they, supposedly, would have no major influence over the central system, and, thereby, assume a secondary position. Nevertheless, they do not become conservative elements that conform to the literary aspects of the target system. On the contrary, in reflecting also on the conception of rewriting (Lefevere, 1992), one could say that Matthews' and Philcox's texts rebel against the dominant ideology and poetics. Matthews' text is defiant to the general linguistic/literary aspect of the target literature, and, as such, may contribute to breaking conventions in the hegemonic language. Philcox's text seeks to rescue Condé's literary plurilingualism, strictly Antillean, so as not to eliminate its aesthetic subjectivity.

By developing a translation that is non-fluent, estranging and heterogenous, which is demonstrative of resistance to the hegemonic English language and culture (Venuti, 2008; Niranjana, 1992), Matthews and her team have created a textual space in which dissimilar peoples and communities are put in relation; in such space, the Black female subjectivity is given visibility, and that is representative of what we have denominated mestizo translation.

As for the Afro-Antillean text, we hope not to mistakenly assimilate the language spoken by the Guadeloupian Black community to Black English, from the United States. Likewise, how can we safeguard, in the English version, the peculiarities of a Portuguese language spoken by the Black community in Brazil? One has to reflect on that, because, in one way or another, it demands a structural change in the sociolinguistic and, therefore, political systems. 


\section{References}

Ahmad, A. (1994). In theory: Classes, nations, literatures. Oxford University Press.

Anzaldúa, G. (1987). Borderlands/La Frontera: the new mestiza. Aunt Lute Books.

Araújo, C. de G. S., Silva, L. de M., \& Silva-Reis, D. (2019). Estudos da tradução \& mulheres negras à luz do feminismo. Revista Ártemis, 27(1), 2-13. https://doi.org/10.22478/ufpb.18078214.2019v27n1.46694

Bassnett, S. \& Lefevere, A. (1990). Translation, history and culture. Pinter.

Bassnett, S. \& Trivedi, H. (1999). Post-colonial translation: Theory and practice. Routledge.

Bassnett, S. (2004). Translation studies. Shanghai Foreign Language Education Press.

Beira, D. (2017). Da negritude cesariana à antilhanidade glissantiana: o caminho para crioulidade e a tradução como prática mestiça. Translatio, 13, 185-200.

Carneiro, A. S. (2005). A construção do outro como não-ser como fundamento do ser. [Doctoral dissertation], Universidade de São Paulo, São Paulo, sP.

Carrascosa, D. (2016). Traduzindo no Atlântico negro: por uma práxis teórico-política de tradução entre literaturas afrodiaspóricas. Cadernos de Literatura em Tradução, (16). http://www.revistas.usp.br/clt/article/view/115270

Condé, M. \& Barbour, S. (2006). Emerging perspectives on Maryse Condé: $A$ writer of her own. Africa World.

Condé, M. (1984). Ségou: Les murailles de terre. Laffont.

Condé, M. (1985). Ségou : La terre en miettes. Laffont.

Condé, M. (2000). Célanire cou-coupé. Robert Laffont.

Condé, M. \& Philcox, R. (2004). Who slashed Celanire's throat? Atria.
Even-Zohar, I. (2005). Papers in cultural research. Unit of Culture Research, Tel Aviv University.

Even-Zohar, I. (2012). The position of translated literature within the literary polysystem. In L. Venuti (Ed.), The translation studies reader. Routledge.

Fanon, F. (1952). Peau noire, masques blancs. Éditions du Seuil.

Felinto, M. (1982). As mulheres de Tijucopapo. Paz e Terra.

Felinto, M. \& Matthews, I. (1994). The women of Tijucopapo. University of Nebraska Press.

Freire, M. (2013). Da Paz, de Marcelino Freire por Naruna Costa. Geledés. https:// www.geledes.org.br/da-paz-de-marcelino-freire-por-naruna-costa/

Gilroy, P. (1993). The Black Atlantic: Modernity and double consciousness. Harvard University Press.

Glissant, É. (1990). Poétique de la relation. Gallimard.

Gonzalez, L. (1988). For an Afro-Latin American Feminism. In B. Stob \& N. Terrell, Confronting the crisis in Latin America: Women Organizing for Change. IsIs International. http://feministarchives. isiswomen.org/47-books/confronting-the-crisis-in-latin-america-women-organizing-for-change/828-for-an-afro-latin-american-feminism

Hill-Collins, P., \& Silva-Reis, D. (2019). Black feminist thought and translation studies: Interview with Patrícia Hill Collins. Revista Ártemis, 27(1), 222-228. https://doi.org/10.22478/ufpb.1807$8214.2019 \mathrm{v} 27 \mathrm{n} 1.46708$

Kilomba, G. (2019). Memórias da plantação: episódios de racismo cotidiano (J. Oliveira, trans.). Cobogó.

Lambert, J.-R. \& van Gorp, H. (1985). On describing translations. In T. Hermans, The manipulation of translation. Croom Helm. 
Lappin-Fortin, K. (2013) Les quatre voix du duo Condé-Philcox. The French Review, 86(3), 535-546. https://www.jstor.org/ stable/23510845

Lefevere, A. (1992). Translation, rewriting and the manipulation of literary fame. Routledge.

Lefevere, A. (2004). Mother Courage's cucumbers: text, system and refraction in a theory of literature. In: L. Venuti (Ed.), The translation studies reader. Routledge.

Niranjana, T. (1992). Siting translation: History, post-structuralism, and the colonial context. University of California Press.

Philcox, R., Kadish, D. Y. \& Massardier-Kenney, F. (1996). Traduire Maryse Condé : entretien avec Richard Philcox. The French Review, 69(5), 749-761.
Spivak, G. C. (1988). Can the subaltern speak? In C. Nelson \& L. Grossberg (Eds.), Marxism and the interpretation of culture. Macmillan.

Toury, G. (1995). Descriptive translation studies: Beyond, revised edition. John Benjamins.

van Doorslaer, L. (2007). Risking conceptual maps. In Y. Gambier \& L. van Doorslaer (Eds.), The metalanguage of translation (special issue) Target, 19(2), 217-233.

Venuti, L. (1998). The scandals of translation: Towards an ethics of difference. Routledge.

Venuti, L. (2008). The translator's invisibility: A history of translation. Routledge.

Vinay, J.-P. \& Darbelnet, J. (1995). Comparative stylistics of French and English: A methodology for translation. John Benjamins.

How to cite this article: Hamilton, N. \& Melo, I. (2020). The critical enterprise in translating Black women writers' authorship: A description on Who slashed Celanire's throat? and The women of Tijucopapo. Mutatis Mutandis. Revista Latinoamericana de Traducción, 13(2), 445-467. https://doi. org/10.17533/udea.mut.v13n2a12 